J. Asiat. Soc. Bangladesh, Sci. 42(1): 115-125, June 2016

\title{
POST-HARVEST QUALITY LOSS OF SMALL INDIGENOUS FISH SPECIES IN SYLHET REGION: ENSURE QUALITY UP TO CONSUMER LEVEL
}

\author{
MD. MOTAHER HOSSAIN ${ }^{1}$ AND A.K. APURBO BARMAN \\ Department of Fisheries Technology and Quality Control, \\ Faculty of Fisheries, Sylhet Agricultural University, Sylhet-3100, Bangladesh
}

\begin{abstract}
The present study was designed to investigate the post-harvest quality loss of locally captured Small Indigenous Species (SIS) based on existing marketing system in Sylhet region. A total of 20 fish harvesters, 30 fish handlers (involve in sorting, loading and unloading, transporting, receiving at market), 10 depot owners, 10 auctioneers, 5 aratders was interviewed and 10 markets were visited to collect data about post-harvest activities and marketing of SIS from some areas of Sylhet and Sunamgonj district from July 2015 to December 2015. At harvesting places (100\%) fish were the best quality (defect point $<2$ ). Fish sold in early market (7am -9 am) were also acceptable (defect point $<2$ to $<3$ ) in terms of quality. After harvesting rough handling (15\%), compactness (3\%), delay icing (10\%), no icing (45\%), marketing process (15\%) and transportation (7\%) lead to loss of a major proportion of total quality. On the basis of defect point average freshness quality of SIS were found $<2$ at harvesting places, $<2$ to $<3$ in landing center, during sorting, $<2$ to $<3$ during transportation and $<2$ to $<4$ at market which were results from different activities associated with SIS handling and marketing.
\end{abstract}

Key words: Small indigenous species (SIS), Post-harvest quality loss, Quality, Ice, Defect point

\section{Introduction}

In Bangladesh, fisheries sector contributes an important role in socio-economic cultural setting, rural employment and food security. About $60 \%$ of the animal protein intake in Bangladesh comes from fish. The average per-capita consumption of fish in Bangladesh is between 20 and $25 \mathrm{~kg}$, while the world average is $13 \mathrm{~kg}$ (DoF 2012). In terms of inland captured fishery, Sylhet region is one of the richest areas of fish production. In this region, fishes are captured from different resources, such as haors, beels, rivers and flood plains etc. Fishes play an important role to meet up the protein demand of this area and also contribute to the economy of the country. Among the captured fishes, small indigenous species (SIS), which grows to a size of $25 \mathrm{~cm}$ (Hossain and Afroze 1991) takes important part of the total catch. These small indigenous fish species are demandable fish item for their taste. In terms of economic and nutritional aspects these SIS are good resources of protein to low income group people. On the other hand, SIS

\footnotetext{
${ }^{1}$ Corresponding author: E-mail: motaher03@yahoo.com
} 
has high nutritive value in terms of protein, vitamins, and minerals (Thilsted et al. 1997). After harvested in large quantity from the haor area SIS are sold in the local and other markets. Quality of the harvested SIS fishes landed for consumption is lost during harvesting and post-harvest handling (Hossain et al. 2012) due to ignorance and/or negligence of the people during harvest, distribution, processing and trade (Nowsad 2004), preservation methods, transportation methods, availability of ice during transportation and selling period etc. All the activities related to the loss of quality also result in serious economic loss of fishermen, middlemen, fish traders and finally consumers. The current study was designed to investigate the quantitative and qualitative changes of small indigenous fishes after harvesting, in different stages of marketing, as well as to evaluate the present status of SIS harvesting, handling, processing, preservation and marketing related to quality of fish and to recommend some appropriate means to maintain quality of SIS/fish.

\section{Materials and Methods}

The study was conducted in two districts namely Sylhet and Sunamgonj, where Sylhet Sadar and Sunamgonj Sadar, the main survey areas in respect of adjacent landing sites, local fish markets were taken under investigation. Data were mainly collected from the fishermen, fish harvester, fish handler and fish traders on the basis of questionnaired interview. Direct observation of landing center, marketing channel, distribution, icing facilities, distance from the landing center, and handling were taken under consideration. The middlemen, aratdars, wholesalers involved in supply, distribution and marketing of fish were selected from whole-sale market (Arot) and retail market for the study. The data were collected over six months from July to December, 2015. The entire situation of the distribution channel of fish including SIS (Hossain et al. 2012) from haor to retailer level was also studied.

Assessment of post- harvest quality loss of SIS in different stages of harvesting, marketing and distribution channel was done according to the modified method of (Nowsad 2010). The method was based on Fish Loss Assessment and Control Tool originally developed by Torry Research Institute, UK (Sakaguchi 1994). To assess the quality of harvested SIS at different stages of distribution channel, at first sensory defect point with numerical scores employed in a sensory analysis was done by using Table 1 (modified based on Howgate et al.1992). General grading of fish obtained through the analysis of defect points (DP) is presented in Table 2. 
Post-harvest quality loss of small indigenous

Table 1. Attributes and defect points for quality assessment of wet fish.

\begin{tabular}{llcl}
\hline \multicolumn{1}{c}{ Attributes } & \multicolumn{1}{c}{ Defect } & Defect points & \multicolumn{1}{c}{ Grade } \\
\hline 1. Odour of neck & a) Natural odour & 1 & Acceptable \\
when broken & b) Faint or sour odour & 5 & Reject \\
2. Odour of gills & a) Natural odour & 1 & Excellent \\
& b) Faint sour odour & 2 & Good \\
& c) Slight moderate sour odour & 3 & Acceptable \\
& d) Moderate to strong sour odour & 5 & Reject \\
3. Colour of gills & a) Slight pinkish red & 1 & Excellent \\
& b) Pinkish red to brownish & 2 & Good \\
4. General & c) Brown or grey & 3 & Acceptable \\
appearance & d) Bleached colour, thick yellow slime & 5 & Reject \\
& a) Full bloom, bright, shining, iridescent & 1 & Excellent \\
5. Slime & b) Slight dullness and loss of bloom & 2 & Good \\
& c) Definite dullness and loss of bloom & 3 & Acceptable \\
& d) Reddish lateral line, dull, no bloom & 5 & Reject \\
6. Eye & a) Usually clear, transparent and uniformly & 1 & Excellent \\
& spread & 2 & Good \\
7. Consistency of & b) Becoming turbid, opaque and milky & 5 & Reject \\
flesh & c) Thick sticky, yellowish or green colour & & \\
& a) Bulging with protruding lens, & 1 & Excellent \\
& transparent eye cap & 2 & Good \\
& b) Slight cloudy of lens and sunken & 3 & Acceptable \\
& c) Dull, sunken, cloudy & 5 & Reject \\
d) Sunken eyes covered with yellow slime & & \\
& a) Firm and elastic & 1 & Excellent \\
elasticity & c) Some softening & 2 & Good \\
d) Limp and flabby & 3 & Acceptable \\
& & 5 & Reject \\
& & & \\
\hline
\end{tabular}

Table 2. Grading of fish on the basis of the defect points.

\begin{tabular}{ccl}
\hline Grade & Average DP & \multicolumn{1}{c}{ Comments } \\
\hline a & $<2$ & Excellent/highly acceptable \\
b & 2 to $<3$ & Good/acceptable \\
c & 3 to $<4$ & Poor/can be accepted with care \\
d & 4 to 5 & Bad/should be rejected \\
\hline
\end{tabular}

\section{Results and Discussion}

Most of the harvested fishes were excellent in quality during harvesting. Fresh SIS (Table 3) were available in all markets depending on proper handling, preservation, distance from harvesting areas and communication status of the harvested area. The small freshwater fishes are more susceptible to spoilage due to their comparative small size and vulnerability of constituent proteins and lipids (Nowsad 2004). Since the quality loss of 
fish was not understood at least up to $50 \%$ of deterioration by common organoleptic means (Sakaguchi 1990), consumers generally took it without any complain on quality. Different activities related to quality loss of SIS are presented in Table 4. Quality loss of SIS at different stages of marketing is shown in Fig. 1.

Table 3. Some SISs which are normally found in Sylhet region.

\begin{tabular}{lll}
\hline Scientific name & Bangla name & Fishbase name \\
\hline Ailia coila & Kajuli,Baspata & Ganjeti cailia \\
Amblypharyngodon mola & Mola, Moa & Mola carplet \\
Anabas testudineus & Koi & Climbing perch \\
Botia dario & Bou, Rani & Bengal loach \\
Chanda nama & Namachanda & Elongate glass-perchlet \\
Chanda ranga & Chanda & Indian glassy fish \\
Channa punctatus & Taki & Spotted snakehead \\
Clarias batrachus & Magur & Walking catfish \\
Colisa fasciata & Khalisa & Banded gourami \\
Corica soborna & Kachki & Ganges river sprat \\
Esomus danricus & Darkina & Flying barb \\
Glossogobius giuris & Bele & Tank goby \\
Gudusia chapra & Chapila & Indian rivershad \\
Heteropneustes fossilis & Shingi & Stinging catfish \\
Lepidocephalus guntea & Gutum & Guntea loach \\
Macrognathus aculeatus & Tara Baim & Lesser spiny eel \\
Mastacembelus pancalus & Guchi & Barred spiny eel \\
Mystus tengara & Buzuri Tengra & Pyjama catfish \\
Mystus vittatus & Tengra & Striped dwarf catfish \\
Nandus nandus & Meni & Gangetic leaffish \\
Notopterus notopterus & Pholi & Bronze featherback \\
Ompok pabda & Pabda & Pabdah catfish \\
Puntius sophore & Jatpunti & Pool barb \\
Puntius ticto & Tit Punti & Ticto barb \\
Osteobrama cotio & Dhela & - \\
Salmostoma bacaila & Chela & Large razorbelly minnow \\
Xenentodon cancila & Kakila & Freshwater garfish \\
\hline & & \\
\hline
\end{tabular}

Harvesting methods had an important role in quality assessment of fish. For selling the fish in the morning markets most of the harvesting operation started at about 4.30 am to 5 am. Fishes which were marketed within one or two hours after harvesting were found to be excellent and fishermen got more prices. Traditional system with mass catch made the small fishes much vulnerable to organoleptic changes shortly after death resulting reduction of price of the fishes. Fixed net were generally used to harvest SIS of fishes from shallow water. In the summer season especially in day time water became hot ultimately affecting the freshness and spoilage rate of the SIS. Hot water temperatures rapidly enhanced the spoilage rate of fish that were accumulated in the net. Nowsad et al. (2010) also reported that fishes were hardly washed with clean water immediately after 


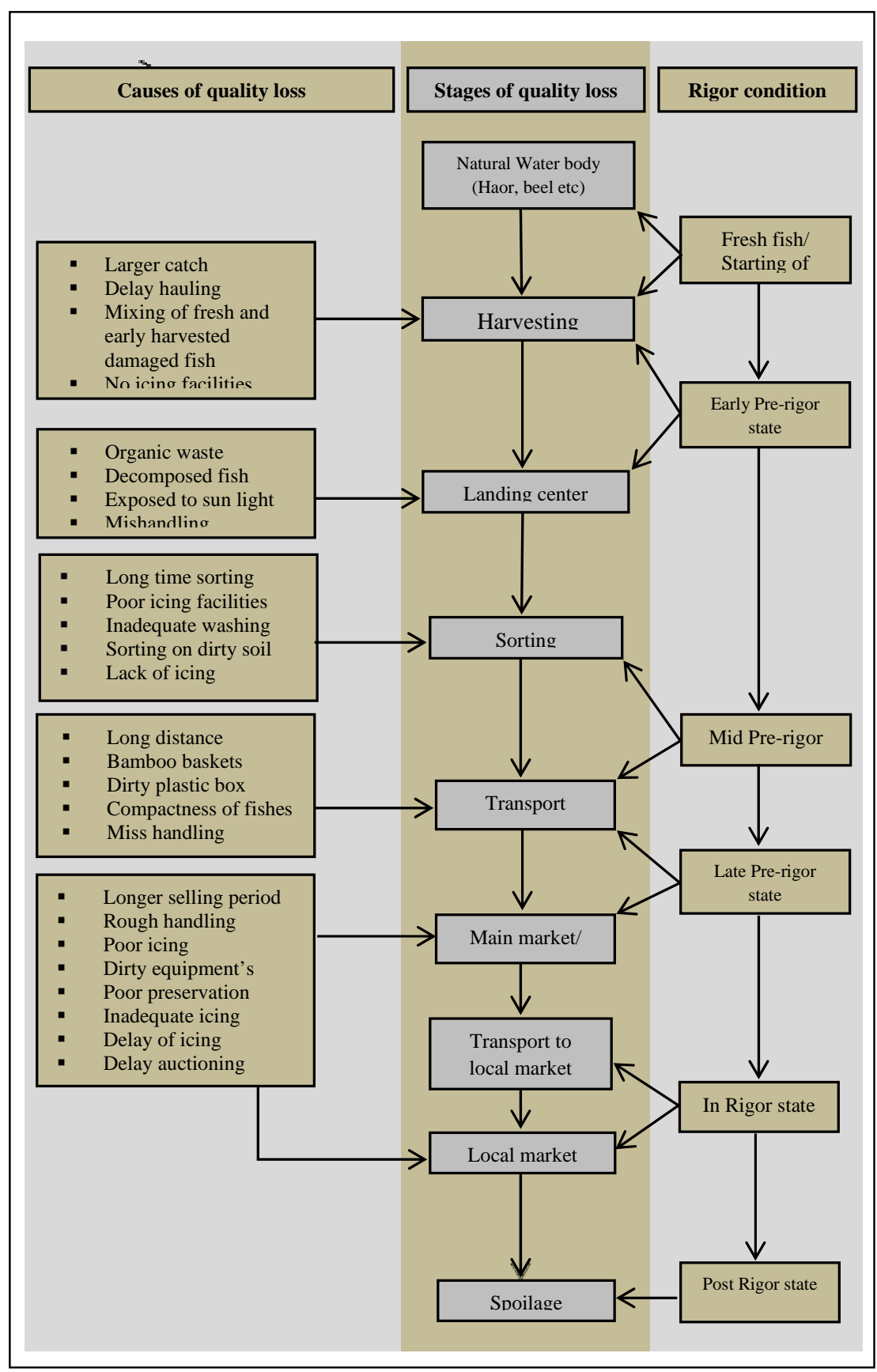

Fig.1. Flow chart of quality loss of SIS at different stages of marketing. 
harvest. Sometimes engine oil of boat mixed with fish are preserved without ice. There was no icing facility for the harvested fish.

Boats were unloaded for first auctioning and also for sorting of mixed SIS catch even with large fishes. Sometimes bank near harvesting place was used as first landing and auctioning place. Generally local fishermen were associated with the unloading of the harvested fish. They hurried during unloading the boat. Smaller fishes especially SIS are more susceptible to physical damage if rough handling is done. Workers were found standing on the fish mass when unloaded. These bad practices created pressure on the top to lower part of the harvested fishes. Traditional bamboo made baskets and plastic boxes are used to unload fish from boat. In some cases human waste, duck waste, cow dung, dead animal body and other organic debris were observed where boats were unloaded. If organic debris was mixed with the catch accidentally or intentionally or unintentionally fish became more susceptible to bacterial decomposition. There was no facility of purchasing ice near temporary auctioning center (Hossain et al. 2012). Sorting after harvesting was done to separate fishes according to its value, price and size etc. Fish which are marketed immediately after landing remains better in quality. Lengthy sorting operations causing long time exposure to sunlight caused quality losses of fishes. Sometimes washing was done by dirty water, where as clean and contaminated free water was rarely used. Although, these activities did not affect the initial qualities but ultimately increased the load of spoilage bacterial population.

Distance was a factor for ensuring quality of small fishes. If communication was better it would require delivering the harvested fish within short time. However, not only the distance, proper transportation with necessary equipment is also required. It was observed that bamboos made baskets were mainly used. According to Hossain et al. (2012) mainly bamboo baskets wrapped in by polythene sheet and recently invented metallic box were used to transport the fish. Recently plastic made baskets are also used. Due to use of bamboo made baskets physical damage of fish as well as bacterial contamination also occurred. No ice was used during transportation of fish. Bamboos made baskets was mainly arranged in one by other vertically with full of fishes. Hossain et al. (2012) also reported that these were not properly washed after using and were kept in a contaminated place.

When harvested fishes were brought in a right way at early morning from water bodies were found fresh and excellent. Hossain et al. (2012) also reported that fish with extra respiratory organ like Baim (Mastacembelaus armatus), Taki (Channa puntatus), Gotchi (Macrognathus aculeatus), Gutum (Lepidocephalichthys guntea), Tengra (Mystus bleekeri) and Shing (Heteropneustes fossilis) were in quit fresh condition. In many cases during auctioning period icing was not done, but after completion of the auctioning the fish sellers use ice for high priced fish and avoid icing for the low priced fish. Nowsad (2004) observed the quality losses due to unavailability of suitable ice-box and ignorance of fishers on adequate handling, icing and freezing of fish. 
In arat, washing, cleaning and icing of fish were hardly seen but sorting was regularly done. Again in the retail market washing, cleaning, sorting, grading and poor icing were done. Hossain et al. (2012) reported that to give fresh look to the fishes sprinkling water frequently over the fish was practiced.

After auctioning certain amount of fishes were marketed to other fish market of Sylhet region. In this case, quality depends on the proper handling, icing and also on preservation period. Generally the fishes which were sold at the afternoon were observed poor in quality in relation to defect point (Fig. 2) except very recent harvested fishes. Ice was available in most large markets of the Sylhet region except some small local markets.

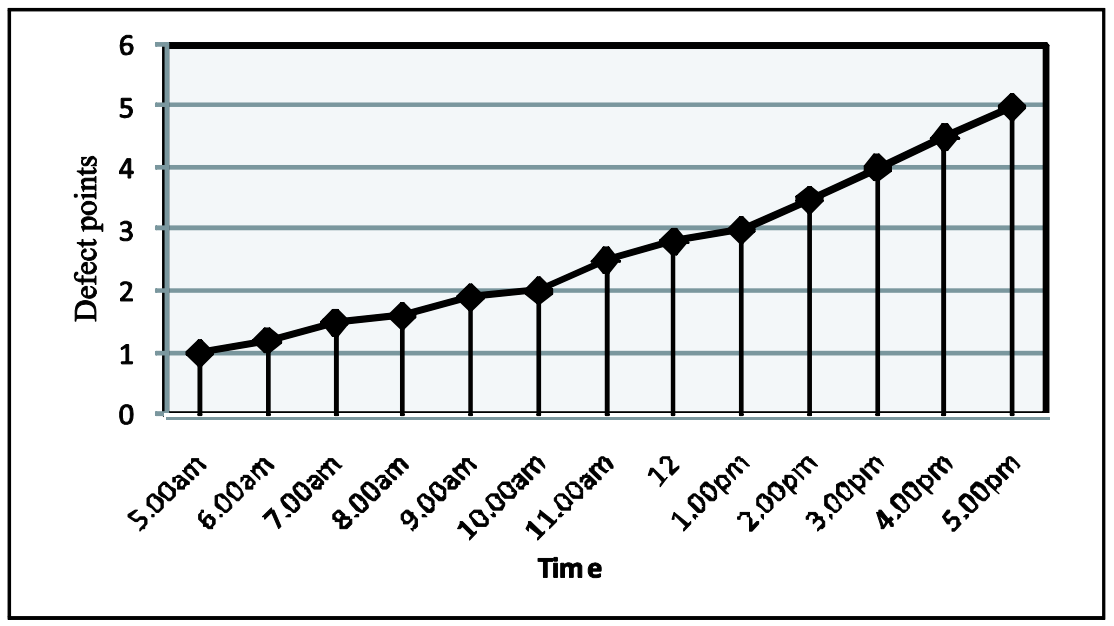

Fig. 2. Changes in defect point with relation to storage time.

In the present study it was found that quality of fishes was deteriorated due to delay in storage time (Fig.2). Major activities related to overall quality (Fig. 3) were lost due to no icing (45\%), delay icing (10\%), rough handling (15\%) marketing process activities (15\%), compactness (7\%) and transportation (3\%). Range of defect point was between $<2$ to $<4$ (Table. 5). Some scientists also observed post-harvest fish losses at different stages of distribution chain from capture to consumption in the country. Huge loss of fish due to very poor or no preservation facilities in Mymensingh area was identified by Hossain et al. (2002). Hossain and Afroze (1991) and Hossain et al. (2002) observed that for inadequate handling and preservation (icing, chilling, and freezing) or storage facilities for farmed Indian major carps, the retail fish traders suffered huge economic loss in terms of low price offered for quality deterioration 


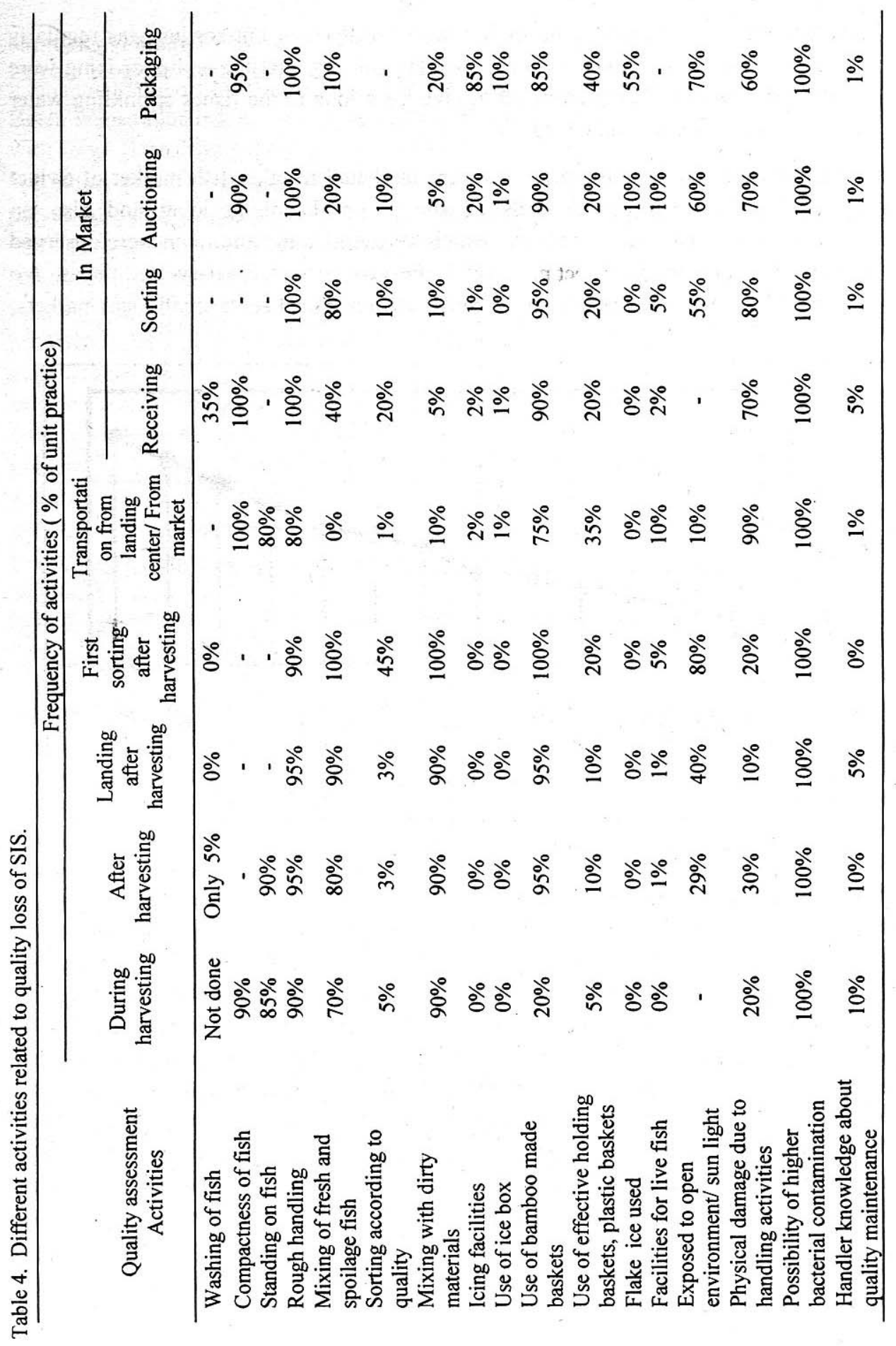


Table 5. Freshness quality of fish at different points.

\begin{tabular}{cccccc}
\hline \multirow{2}{*}{ Defect point } & \multicolumn{5}{c}{ Quality of fish at different point } \\
\cline { 2 - 6 } & $\begin{array}{c}\text { Quality at } \\
\text { harvest }\end{array}$ & $\begin{array}{c}\text { Quality at } \\
\text { landing }\end{array}$ & $\begin{array}{c}\text { Quality at } \\
\text { sorting }\end{array}$ & $\begin{array}{c}\text { Quality at } \\
\text { transportation }\end{array}$ & $\begin{array}{c}\text { Quality at } \\
\text { market }\end{array}$ \\
\hline$<2$ & $100 \%$ & $100 \%$ & $95 \%$ & $95 \%$ & $80 \%$ \\
2 to $<3$ & $0 \%$ & $0 \%$ & $2 \%$ & $2 \%$ & $10 \%$ \\
3 to $<4$ & $0 \%$ & $0 \%$ & $2 \%$ & $3 \%$ & $8 \%$ \\
4 to 5 & $0 \%$ & $0 \%$ & $1 \%$ & $0 \%$ & $2 \%$ \\
Range of & $<2$ & $<2$ to $<3$ & $<2$ to $<3$ & $<2$ to $<3$ & $<2$ to $<4$ \\
defect points & $<$ & & & & \\
\hline
\end{tabular}

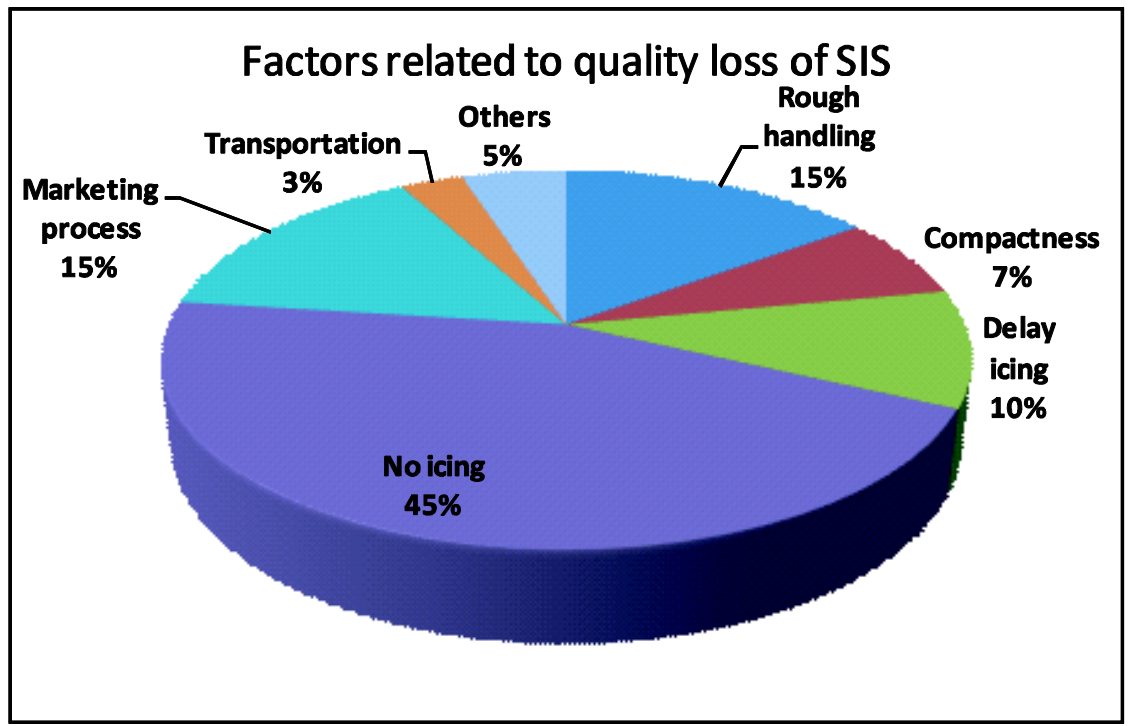

Fig. 3. Major activities related to overall quality loss (in percentages).

Some recommendations to ensure better quality of sis after harvesting: Small Indigenous Species of fishes are more popular in present market condition. Some recommendations are mentioned to ensure better quality of SIS depending on the existing situation and problems that are faced by the fishermen, sellers and customers.

1. Training of harvesters, fishermen about "Good Harvesting Practices" can be introduced. Fishermen should be trained up about some basic knowledge of harvesting technology so that it would be helpful to ensure the better quality of fish.

2. Some fixed landing centers should be established near harvesting areas with concrete made platform or temporary modified system (using of polythene on soil to perform the sorting), washing system and icing facilities.

3. In most of the areas where SIS is harvested have no icing facilities. To maintain the quality of fishes icing is indispensable. It is true that to ensure the icing facilities in every 
place is very difficult but in some cases it is possible. In this case insulated van can be used for transportation.

4. Bamboos made baskets are commonly used for handling and transportation. Use of plastic boxes is not yet popular. In this case plastic boxes or insulated boxes can be used to carry the SIS as well as to maintain the better quality.

5. In the fish markets mishandling during harvesting, transportation, auctioning which is related to quality loss should be avoided.

6. Proper sanitation practices by the handlers in all cases through harvesting to marketing must be introduced to mitigate the above mentioned problems.

7. A time schedule can be maintained for selling of fish. Morning fish markets would be better for selling of fish to reduce the quality loss. Since most of the harvested fishes are brought at market before $9 \mathrm{am}$, so it is evident that fish which are sold before $10 \mathrm{am}$ is better in quality. Beside this, a temporary based morning fish market (duration 2 to 3 hours) can also be established near the landing center and harvesting area which would ensure better quality of fish for the local consumers and reduce transportation cost, loss of quality during transportation.

\section{References}

DoF (Department of Fisheries). 2012. Fisheries Resources of Bangladesh at a Glance (2010-2011). In: National Fisheries Week-2012 Souvenir. Department of Fisheries, Ministry of Fisheries and Livestock, Government of Bangladesh. 144 pp.

Hossain, M. A. and S. Afroze. 1991. Small fish as a resource in rural Bangladesh. Fish. Biol. 9 (2): 16-18.

Hossain, M.A.R., M.Z. Ali, M.N.A. Khanam S. Debnath and A.K.M.R. Amin. 2002. Participatory rural appraisal with small indigenous species of fish (SIS) retailers in two fish markets. Progress. Agric. 13 (1 \& 2): 133-138.

Hossain, M.M., M.N. Hassan and A.K.M. A. Nowsad. 2012. Extent and Causes of Quality deterioration of Wet Fish in Fish Value Chain in Sylhet-Sunamgonj Area in Bangladesh. Journal of Fisheries International.7(2): 30-34.

Hossain, M.M., M.N. Hassan, U.J. Lithi and A.K.M. A. Nowsad. 2012. Quality deterioration of wet fish caught in Mymensingh farm in different steps of distribution channel towards Dhaka. J. Bangladesh Agril. Univ. 10(2): 331-337.

Howgate, P.A., K. Johnston and J. Whittle. 1992. Multilingual Guide to EC Freshness Grades for Fishery Products.Torry Research Station. Food Safety Directorate, Ministry of Agriculture, Fisheries and Food, Aberdeen, Scotland. 32 pp.

Nowsad, A.K.M. A. 2004. Landing center monitoring. Report on a survey on a research done in collaboration with Bangladesh center for Advanced Studies and Natural resources Studies, ECFC Field Rep. 2005. 189 pp.

Nowsad, A.K.M. A. 2010. Post-harvest Loss Reduction in Fisheries in Bangladesh: A Way Forward to Food Security. Final Report PR no.5/08.Food and Agriculture Organization (FAO) of the United Nations, Dhaka. 171 pp. 
Nowsad, A.K.M. A., M.N. Hassan, M.M. Hossain, M.S. Hoque, M.A. Siddique and M. R. Islam. 2010. Quality improvement of exportable fish and prawn through post-harvest loss reduction in Kulierchar Under participatory stakeholder-based approach. Progress. Agric. 21(1 \& 2): 105-115.

Sakaguchi, M. 1994. Objective and subjective method for measuring freshness of fish. Department of Fisheries, Faculty of Agriculture, Kyoto University, Kyoto, Japan.

Thilsted, S.H., N. Roos and N. Hasan. 1997. The role of small indigenous species in food and nutrition security in Bangladesh. NAGA- The ICLARM Quarterly, July-Dec.:13-15 pp.

(Revised copy received on 01-06-2016) 